\title{
Strategic Gestures in Bill McKibben's Climate Change Rhetoric
}

\author{
Peter K. Bsumek ${ }^{1 *}$, Steve Schwarze ${ }^{2}$, Jennifer Peeples ${ }^{3}$ and Jen Schneider ${ }^{4}$ \\ ${ }^{1}$ School of Communication Studies, James Madison University, Harrisonburg, VA, United States, ${ }^{2}$ Department of \\ Communication Studies, University of Montana, Missoula, MT, United States, ${ }^{3}$ Department of Languages, Philosophy, and \\ Communication Studies, Utah State University, Logan, UT, United States, ${ }^{4}$ School of Public Service, Boise State University, \\ Boise, ID, United States
}

OPEN ACCESS

Edited by:

Chris Russill,

Carleton University, Canada

Reviewed by:

Simon Dalby,

Wilfrid Laurier University, Canada

Terence Check,

College of Saint Benedict and Saint John's University, United States

${ }^{*}$ Correspondence:

Peter K. Bsumek bsumekpk@jmu.edu

Specialty section:

This article was submitted to Science and Environmental Communication,

a section of the journal Frontiers in Communication

Received: 19 February 2019 Accepted: 10 July 2019 Published: 19 August 2019

Citation:

Bsumek PK, Schwarze S, Peeples J and Schneider J (2019) Strategic Gestures in Bill McKibben's Climate Change Rhetoric

Front. Commun. 4:40. doi: 10.3389/fcomm.2019.00040
Although Bill McKibben is widely recognized as one of the leading strategists of the US climate change movement, several observers identify significant limitations to his approach to climate advocacy and politics. These criticisms are based on his reliance upon "symbolic gestures," such as campaigns to promote fossil fuel divestment and stop fossil fuel infrastructure construction. In this essay we reconsider McKibben's work, drawing specifically on his speeches given in the US from 2013 to 2016 in support of the fossil fuel divestment campaign and campaigns attempting to block the construction of fossil fuel infrastructure, in order to show how McKibben's strategic orientation is grounded in a politics of gesture. His speeches provide a model for how to reconceive gestures and assemble them for political ends, and expand a sometimes narrow focus on policy mechanisms. Beyond the case of McKibben our analysis contributes the concept of strategic gestures to identify and theorize social movement interventions that have significant symbolic and material consequences.

Keywords: articulation, climate change, rhetoric of inevitability, social movements, strategic gestures

\section{INTRODUCTION}

In 2006, author Bill McKibben found himself at "the end of my relatively quiet life as mostly a writer and the start of a hectic stint being mostly an activist" (McKibben, 2016a). McKibben had been speaking and writing about climate change since his 1989 publication of The End of Nature, one of the most influential books on climate change for a general audience. Despite growing scientific evidence and warnings about the climate crisis, there had been minimal political action and only modest grassroots activism on the issue, and McKibben was frustrated. "I wanted to do something. But there was no real climate movement to join” (McKibben, 2016a).

So McKibben set out to launch just such a movement. Starting with a march across his home state of Vermont, McKibben played a central role in a series of efforts to generate a large-scale, influential climate movement. In 2007, he and other organizers coordinated "Step It Up," a set of climate events in over 1,400 communities in the US, intended as a call for Congressional action to reduce carbon emissions $80 \%$ by 2050 . This network of activists subsequently formed 350 .org, a 501(c)3 group in the US that connects and mobilizes climate activists around the world. Since then, McKibben has been a prominent voice in opposing the Keystone XL pipeline, fostering fossil fuel divestment campaigns, and orchestrating the 2014 and 2017 People's Climate Marches. His 2012 Rolling Stone article (McKibben, 2012), "Global Warming's Terrifying New Math," received over 14,000 online comments and was reproduced or hyperlinked thousands of times, "making it one of the most widely circulated online articles in Rolling Stone's history" (Nisbet, 2013, p. 47). The essay was a galvanizing rhetorical moment in the climate movement. As journalist Mark Hertsgaard (2014) put it, McKibben's efforts pushed "the threat of climate change into the 
mainstream American political agenda." Communication scholar Matthew Nisbet acknowledges that McKibben is "arguably the most prominent climate change activist in the United States” (Nisbet, 2013, p. 41).

Although McKibben refers to himself as an "unlikely activist" (McKibben, 2013a) and resists the label of a movement leader, many observers claim that "he comes up with many of the big ideas about what to do, functioning as a-if not the-major strategist of the US climate change movement" (Bronstein, 2014). Shortly after the 2014 Peoples Climate March, McKibben stepped down as executive director of 350.org, explaining that doing so would leave him "more energy and opportunity for figuring out strategies and organizing campaigns" (Goldenberg, 2014) ${ }^{1}$. In turn, much of the scholarly analysis of McKibben focuses on the strategic dimensions and limitations of his work. For example, a multi-site study of the Step It Up (2007) events provides varying assessments of the efficacy of messages circulating across those sites (Endres et al., 2008, 2009). J. Robert Cox criticizes McKibben's approach to climate politics as failing to account for the strategic "considerations of effect" that can enable a movement to "contribute to a sustained influence" at the scale necessary to address a problem as significant as climate change (Cox, 2009, 2010).

Similarly, Nisbet, while acknowledging McKibben's influence, argues that his utopian rhetoric may appeal to the environmental base but has been unable to generate broad support or advance a viable political agenda. McKibben is more style than substance, argues Nisbet; his symbolic actions and political gestures, such as protests and non-violent civil disobedience, do not translate into "a pragmatic set of [policy] choices designed to effectively and realistically address the problem of climate change" (Nisbet, 2013, p. 3).

While noting merit in these critiques, we take a different approach to McKibben's work in order to propose an alternative mode of thinking about the strategic dimensions of climate activism and advocacy. Based on an analysis of McKibben's speeches, we offer the notion of strategic gestures as a concept to identify and theorize a rhetorical assemblage of movements, actions, and performances that have significant symbolic and material consequences. Whereas some critics use the label of gesture, or "gesture politics," to dismiss particular interventions as empty, ineffectual, or "merely" symbolic, we contend that McKibben's speeches provide a model for how to reconceive gestures and assemble them strategically for political ends. In other words, we argue that McKibben's strategic orientation is productively considered in terms of a "politics of gesture." Our analysis identifies four rhetorical actions that contribute to the strategic potential of gestures: promoting articulation and solidarity, interrupting dominant discourses, enacting alternative futures, and applying leverage at sites of decision making. In turn, the concept of strategic gestures provides scholars and activists alike with new insights into the relationship between rhetoric and social change.

In the subsequent analysis of McKibben's speeches, first we discuss McKibben's role as a strategist and speaker. Then we

${ }^{1}$ McKibben remains on the board of directors of 350 .org. reconsider criticisms of McKibben made on strategic grounds. As noted above, both Cox and Nisbet argue that McKibben's strategies are inadequate to produce substantive change. In doing so, we review the concerns of those critics before developing our own interpretation of "the strategic" in McKibben's public address. In the third section we define and develop the concept of strategic gestures demonstrating how they can be utilized to build social movements and solidarity, interrupt dominant discourses, enact alternative futures, and apply leverage at local sites of decision making in order to produce wider systemic effects. In the fourth section we discuss practical implications of our analysis of strategic gestures focusing on their potential to produce social change. Finally, we conclude with some theoretical implications for scholars of environmental communication and social movement rhetoric. Ultimately, we present the concept of strategic gestures in order to account for and theorize how disparate acts of resistance and rhetorical interventions can be made to act in concert to produce social change and transform complex systems.

\section{BILL MCKIBBEN, STRATEGIST, AND SPEAKER}

Given McKibben's prominence, it is not surprising that scholars in environmental communication and related disciplines have closely analyzed his work (Eckersley, 2005; Luke, 2005; Yearley, 2006; Cox, 2009; White, 2011; Merrill, 2012; Mitra, 2013; Nisbet, 2013; Ytterstad, 2015). However, most scholars have concentrated on his writing or his organizations rather than his speeches. Perhaps this is because McKibben's speeches and speaking style may not seem that notable. He began his 2015 Lannan Keynote Address at Georgetown University by confessing, "And what in some ways I would still most like to be doing. . . is thinking about things and writing them down." He also drew attention to his lack of presentational polish by noting, "I may stumble a bit here and there" (McKibben, 2015a) ${ }^{2}$. He frequently makes such apologies, adopting humility to disarm and build trust with audiences, and his speeches contain incomplete thoughts, digressions, and apparent contradictions.

However, McKibben's oratory is significant for environmental communication in spite of its seeming lack of artistry. First, compared to his written works, which seek a general readership and rely upon familiar forms of environmental apocalyptic narrative and romanticism, McKibben's speeches are primarily addressed to those who already identify with the climate movement. Rather than minimize this type of rhetoric as simply "preaching to the choir," we take it seriously as a means of promoting the "mobilization capacity" of the climate movement (Brulle, 2010). When McKibben speaks to activists, he seems to understand that in order to be moved to further action, his audiences need to see how local actions will contribute to the larger goal of "solving" climate change.

\footnotetext{
${ }^{2}$ We have attempted to maintain McKibben's speaking style by including the stops, starts and changes in thought direction, as they also reflect his extemporaneous delivery and reflective nature in presentation.
} 
Second, this audience-related constraint in the rhetorical situation leads McKibben to foreground his strategic thinking in his speeches. Whereas, his writings tend to focus on framing climate science for general audiences, his speeches provide a context and template for how climate activists might connect the local and the global, and the personal and the political, in ways that attract followers and advance the movement. Movement strategy is especially salient in the speeches we draw upon for our analysis: analyzing 11 publicly available speeches given by McKibben between 2013 and 2016, with particular attention given to his keynote address for the 2015 Lannan Symposium at Georgetown University. Several of these speeches were part of McKibben's 2012-2013 "Do the Math" tour, which sought to mobilize audiences around fossil fuel divestment and the keeping carbon in the ground campaign.

Third, these speeches reflect a moment in which the US climate movement was at a strategic crossroads. Hopes for strong climate action during the Obama administration were dashed by a weak agreement at the 2009 Conference of Parties meeting in Copenhagen and the failure of cap and trade legislation in 2010. However, in the years following, the climate movement also found reasons to be hopeful. In 2014, the rollout of the Clean Power Plan and the significant turnout for the People's Climate March suggested that public awareness was growing and policy action was not far behind. Also, President Obama vetoed legislation that would have forced construction of the Keystone $\mathrm{XL}$ pipeline to proceed, eventually denying the permit for its construction in 2016 $6^{3}$. Thus, McKibben's speeches occur at a critical strategic moment for the US movement, and they can be interpreted as efforts to narrate the movement's successes and chart a path forward. Our findings may have even greater significance in the current period with its heightened political infighting, the US's exodus from global climate agreements, and the backsliding of federal environmental policy, making the need for strategic gestures even more pressing. At the end of this paper, we reflect on what McKibben's work, and our conceptualization of strategic gestures, might mean in the age of Trump.

Because of the compelling environmental rhetorical situation described above, especially the characteristics and motivations of the particular audiences, we chose to focus on McKibben's US speeches for this analysis. That noted, McKibben's work writ large is global and international in content and reach. His presentations reference environmental disputes and climate "wins" from around the globe. The Fossil Free: Divestment website shows activity from religious organizations, NGOs and governments from every continent other than Antarctica. Among those who divest are "some of the world largest pension funds and insurers, dozens of world-class universities, the world's largest sovereign wealth funds, the country of Ireland, major capital cities, as well as philanthropic foundations, health associations and world- renowned cultural institution" (Hazan et al.). Equally, the website for 350.org shows it having organizations that exist across the map (https://350. org). As is frequently noted by McKibben, each site has its

\footnotetext{
${ }^{3}$ This decision was reversed by newly elected President Trump in early 2017 . The campaign to stop and delay this pipeline continues as of this writing.
}

own environmental issues, its own barriers, and its own points of leverage, varying the opportunities for strategic gestures by location.

\section{CLIMATE ADVOCACY AND THE QUESTION OF THE STRATEGIC}

Cox advances his notion of "the strategic" as a heuristic for rhetorical invention in two essays that directly analyze McKibben and the Step It Up campaign (Cox, 2009, 2010). While that campaign appeared to generate interest among farflung audiences around a consistent message, newly mobilized audiences were not organized to apply political pressure in support of the campaign's goals. Cox (2010) diagnoses the problem with this approach in terms of a faulty belief about how democratic political change takes place-in other words, a problem of strategy:

The implicit, strategic assumption seemed to be that, with news (and images) of enthusiastic and inspiring citizens sounding an alarm, more people would become informed and wouldconsistent with a democratic polity-rise up and demand that elected officials take necessary steps to protect our life-sustaining planet. (p. 127)

Cox's criticism lies less with the framing of Step It Up's messages or its awareness-raising efforts than with the failure to steer those efforts toward a consequential, systemic impact. This failure to align communication practices with opportunities to transform systems of power is at the heart of Cox's interest in "the strategic." In his words, the notion of the strategic attempts to "account for communicative effects-how the application of a certain force, and the citizen mobilizations aligned with this, enable or initiate a process of events that influence larger effects within a system of power" (Cox, 2010, p. 131).

Nisbet shares Cox's interest in seeing more concrete political effects, but his major criticism lies with McKibben's alleged lack of pragmatism. He develops this argument in an in-depth white paper, tellingly titled "Nature's Prophet," which surveys McKibben's influence as a "Journalist, Public Intellectual, and Activist" since The End of Nature (Nisbet, 2013). Nisbet's central argument is that, "As a public intellectual, Bill McKibben has failed to offer pragmatic and achievable policy ideas;" throughout the paper, he consistently positions McKibben as having "little tolerance for political pragmatism" and clinging to the utopian values of deep ecology "rather than a pragmatic set of choices designed to both effectively manage the problem and to align a diversity of political interests in support of compromise" (Nisbet, 2013, p. 50-54). McKibben's moralistic rhetoric, his desire for small-scale agrarianism, his opposition to certain technologies, and his focus on symbolic acts of protest are marshaled by Nisbet as evidence of the narrow appeal of McKibben's activism. Furthermore, Nisbet argues that when faced with the failure of conventional policy proposals, McKibben refuses to adjust his strategy. "The response...from McKibben and other environmentalists has been to double-down in their commitment to their policy paradigm, attributing failure 
to the political prowess of conservatives and industry, and to a corresponding lack of grassroots pressure and moral outrage" (Nisbet, 2013, p. 50).

Nisbet's focus on pragmatism and Cox's focus on system transformation represent different approaches and assumptions with respect to what might make an intervention "strategic." Nisbet's concerns emerge from a policy orientation rather than the social movement/pressure group perspective of Cox. Nisbet's (2014) critiques also represent an ecomodernist commitment to technological solutions to climate challenges, whereas Cox (2009) is more concerned with transforming the "complex whole" of economic, political, and ideological systems toward a low-carbon society. Likewise, while Cox (2010) is motivated by the need for "changes on the scale and timetable that climate and other system crises require" (p. 125), Nisbet (2013) favors incremental policy reforms; in his view, "breaking down the wicked nature of climate change into smaller, interconnected problems, achieving progress on these smaller challenges becomes more likely" (p. 51).

These differences illuminate some of the considerations and political visions that might inform strategic thinking in climate activism and environmental advocacy more generally. Cox and Nisbet's criticisms surface several key issues for strategizing about political and social change: what breadth and depth of social solidarity is needed to leverage change? To what degree should advocates challenge, or align with, dominant discourses, values, and interests? How do they craft a vision of the future that is both appealing and achievable? And where are the optimal sites for altering systems of power? Such questions are at the heart of strategic thinking about social change.

McKibben's speeches provide a distinctive set of answers to these questions. His take on the strategic is less dismissive of the role of so-called "symbolic" politics than Nisbet's, and his turn toward divestment arguably reflects greater attention to contingent openings in systems of power than was displayed in the Step it Up campaign, which Cox took issue with. Cox's focus is on leverage in economic and energy systems, perhaps at the expense of attention to the ideological and political systems that may also contribute to social and policy change. Strategic gestures, as deployed by McKibben, articulate how economic, political, and ideological systems can be leveraged in concert with each other to produce change. His approach is captured well by Engler and Engler (2013), who argue that "if they are to spark mass movement, campaigns must be built with symbolic as well as instrumental considerations in mind; they must achieve outcomes that perpetuate further movementbuilding, even if they do not immediately advance a given policy goal" (online). McKibben's enactment of this principle is a significant instance of this move in social movement strategizing. We argue that it can be productively theorized as a politics of gesture that is orchestrated rhetorically through the assemblage of strategic gestures.

\section{STRATEGIC GESTURES}

The concept of gesture has traditionally been considered an adjunct to speech and associated with the canon of delivery in the study of rhetoric. However, some rhetoricians are rethinking gestures as part of a broader interest in body rhetoric and its inventional possibilities. Scholars such as Debra Hawhee and Cory Holding recuperate theories that explain how gestures give shape to speech and facilitate connections between bodies, rather than functioning as mere ornaments to rational discourse. Hawhee's (2006) reading of Sir Richard Paget, for example, identifies the mimetic and contagion-like character of gesture that not only moves a body to speech, but also facilitates communion with others. "The ability for those movements to 'catch on' across bodies helped him account for the spread and resulting 'staying power' of language. Put still more simply, speech gestures are communicative because they are both communicable and communal" (p. 335). Likewise, Holding (2015) re-reads John Bulwer's famed gesture manuals as what could be called a body-positive theory of invention, suggesting that contemporary rhetoricians can use Bulwer to "offer a theory of how gestures communicate, attitudinize, and forge pathways to listening, mutual acknowledgment, and identification" (p. 416).

The generative role of gestures heightens their significance as means for conserving or resisting established relations of power. Hariman (1992), for example, illustrates how the courtly style relied on the "displacement of speech by gesture" as a form of "social control that makes the decorous body the sign of order" (p. 160). Conversely, Olson and Goodnight (1994) use the social controversy over fur to identify "gestures that widen and animate the non-discursive production of argument" as oppositional rhetorical strategies (p. 252). In their view, "non-discursive arguments work-in the new, 'free' space of reassociation-to redefine and realign the boundaries of private and public space" (p. 252). More broadly, Phaedra Pezzullo calls attention to the importance of bodies and non-linguistic acts as components of cultural performances that critically interrupt dominant discourses and contribute to "the rhetorical force of counterpublics" (Pezzullo, 2003, p. 361).

These perspectives on the inventional and oppositional possibilities of gesture complicate any easy dismissal of gestures and their relevance to politics and social movements. Cambridge Dictionary ${ }^{4}$ (online) defines "gesture politics" as "any action by a person or organization done for political reasons and intended to attract attention but having little real effect." Similarly, Christopher Caldwell (2005) notes, "The expression 'gesture politics' generally describes the substitution of symbols and empty promises for policy." In contrast, other critical and cultural theorists position gesture as an important concept for theorizing power and resistance in ways consistent with Pezzullo's perspective. Lindsay Reckson (2014) explains that "cultural studies scholars have understood gesture as both communicative and performative; gestures can express semantic content, but they can also enact (and reenact) cultural histories, identities, and commitments." Scholars of performance and performativity, she adds, formulate gestures as "movements that produce, reproduce, and potentially interrupt embodied structures of power" (online). Building on this definition of

${ }^{4}$ Cambridge Dictionary, "Gesture politics." Available online at: https://dictionary. cambridge.org/us/dictionary/english/gesture-politics 
gesture, we advance the notion of strategic gestures as a rhetorical assemblage of movements, actions, and performances that are intended to generate effects larger than a sum of individual or particular acts in systems of power. This approach to gestures embraces not an empty "gesture politics," but a politics of gesture that takes seriously the political possibilities of certain kinds of gestures.

This conception of strategic gestures emphasizes the rhetorical processes through which gestures become strategic. Importantly, our plural description suggests that gestures are not necessarily strategic in isolation. Gestures become strategic when they are made to complement and amplify each other to effect systemic change. Because economic, political and ideological systems function in concert with each other to produce, in Cox's (2009) words "a complex whole articulated in dominance and resistant to change," transforming systems necessitates multiple gestures designed to leverage change across the whole (p. 399). Such gestures might include traditional symbolic interventions such as speeches, image events, and protests, and they might include material interventions such as the installation of renewable energy, the use of electric cars, and the divestment of institutional funds from fossil fuel industries. Each of these actions may be perceived as little more than a symbolic gesture, but when assembled together they can function as strategic gestures to produce social movement and systemic change.

The rhetorical actions accomplished through gestures provide another means for considering how gestures become strategic. Our analysis of McKibben's speeches identifies four types of rhetorical action that contribute to the strategic potential of gestures. First, strategic gestures can facilitate articulation, linking different and dispersed groups, causes, and issues to generate social solidarity (Laclau and Mouffe, 1985; Greene, 1998; DeLuca, 1999; Stormer, 2004; Peeples, 2011). As Brian Massumi (2015) puts it, "The gesture is a call to attunement. It is an invitation to mutual inclusion in a collective movement" (p. 105106). Second, strategic gestures can interrupt dominant discourses (Pezzullo, 2001) and "usher into the public realm aspects of life that are hidden away, habitually ignored, or routinely disconnected from public appearance" (Olson and Goodnight, 1994, p. 252). Third, strategic gestures can enact and display alternative futures. Massumi (2015) identifies how gestures are both affective, "felt as directly as they are thought," and speculative, as they "convoke potential and carry alternatives" (p. 207). Strategic gestures capitalize on this to display new modes of being and action as possible and desirable. Fourth, strategic gestures can apply leverage at sites of decision making to alter systems of power relations. Even as the performative and affective power of gestures may signal cultural change, Cox's notion of the strategic helps us consider how gestures produced at the right time in the right place can leverage systemic change.

\section{ASSEMBLING GESTURES IN MCKIBBEN'S SPEECHES}

McKibben's speeches lean heavily on the scenic construction, first articulated in "Global Warming's Terrifying New Math," of a melodramatic climate "battle." In that piece, McKibben squarely positions the fossil fuel industry as "Public Enemy \#1" in a battle over the public interest. His Lannan keynote surveys the scene of climate politics as "maybe the most important pitched battle in human history" (McKibben, 2015a). The battle is urgent; there is no time for gradualist, market-driven, evolutionary social change. Instead, he argues, "We get, if we get anything, the difficult change that is won by winning power. And for that power to be won, we need a set of weapons that work to our advantage. We can't win it with money, because they have more of it than we do. They have more than anybody" (McKibben, 2015a). Because the "other side" has more money "and hence controls more political leverage," the battle must be fought using non-traditional political means (McKibben, 2015a).

This scenic construction opens a space for McKibben to talk about the kinds of interventions that we are calling "strategic gestures." Because traditional avenues for enacting policy change are closed, McKibben (2015a) makes a case for the creative use of symbolic actions. "Our weapons," he argues, "have to be the other ones. Passion, spirit, creativity, um, um, our bodies.... The role of the imagination in these fights." There are two important aspects of McKibben's discussion of symbolic weapons that inform our theorizing of strategic gestures.

First, McKibben (2015a) constitutes the battle as a contest of momentum in which each side attempts to demonstrate what will be inevitable: "It's a particular kind of fight... It's a battle for momentum. A battle for winning the sense of what's inevitable or not. What's the world going to look like. And that battle is, wellthat's everything." Here McKibben lays bare how the climate "battle" is a contest for ideological hegemony, for commonsense understandings not about what the future should look like, but about what it will look like. McKibben's battle lines resonate with Massumi's (2015) observation that, "capitalism hardly bothers to assert its rationality any more, contending itself with creating the affective 'fact' of its inevitability" (p. 111). McKibben's symbolic weapons, then, are utilized both to challenge the affective "fact" of a fossil fuel economy and call an alternative future into being.

Second, the contest for the cultural commonsense about the future is fought with a series of gestures over an extended period of time. In his Lannan speech, for example, argues:

In a fight like that-and here's maybe the crucial word for me for this talk-in a fight like that, each gesture becomes essential. There's a kind of, um, fight of gestures, of images that are brought forward, and, and, and each time a gesture is made, each timewell, each time there's a new solar roof top, that's the kind of easy and obvious one-but each time there's a divested college, or even a strong, beautiful movement for it on a college, um, um, that sense of what's going to happen begins to shift McKibben (2015a).

In other words, each gesture in the fight for momentum contributes to a larger goal. Social change is produced not in one fell swoop, but over an extended period of time. As such, gestures should not be viewed in a vacuum, but as part and parcel of an extended effort to build solidarity, enact a vision of a low-carbon future, and effect systemic change. 


\section{Articulating Solidarity}

In almost every speech, McKibben registers a litany of successes related to climate change: acts of individuals and groups, government policies, or technological advances. During a speech in Brooklyn, before the 2016 Climate Talks in Paris, McKibben rallies:

\begin{abstract}
No kidding, no kidding, this is powerful! I mean, look, that one mine that Charlie was talking about. A year ago we were pretty sure it was going to get built, and if it had been, it would have, just that one valley, put $5 \%$ of the carbon in the atmosphere necessary to take us past two degrees. One mine. If they have stopped it, same thing all over the world. It's not as if any of us started this movement. Local people, often indigenous people, in defending their land against intrusion for many years. More and more, more and more [clapping]-more and more, they've been winning. Look, in India, fishermen, farmers in the village of Sompeta. They waged a 5-year battle to keep this giant coal mine from destroying their town. Now, they won. They won at the cost of three activists being killed along the way, but they won. South Africa, intense pressure in the last months from local activists persuaded [a] big company, GDF Suez, to pull support for the new coal plant at Thabametsi. We're starting to win.
\end{abstract}

(McKibben, 2015c)

In other speeches, McKibben includes the Galilee Basin in Australia (McKibben, 2015b), Copenhagen and the Tar Sands in Canada (McKibben, 2015d), rooftop solar panels (McKibben, 2013b), the trial of the Delta 5, and the Lummi Nation and kayaktivists (McKibben, 2016b), among many other acts of resistance.

Discussing climate change movement strategies, but also providing insight into his rhetorical tendencies, he states: "There is no one answer to climate change. There is no silver bullet. There may be enough silver buckshot if we gather it all up" (McKibben, 2013b). By gathering the buckshot, McKibben is not only providing a sense of momentum; he is also articulating and building solidarity and affiliation with the climate cause.

Massumi's description of gesture as a call to attunement resonates with the concept of articulation as it has been developed in communication scholarship. In particular, it is similar to DeLuca's (1999) turn to articulation to interpret the enacted resistance of environmental activism. Articulation is typically understood as a linking of disparate elements that modifies their meaning. This linkage produces "chains of equivalence," where those elements are constituted as signs of some larger phenomenon and evidence of domination; "each link in the chain remains distinct, but they operate together, in concert... around an agenda of equivalence" (Purcell, 2009, p. 159). From this perspective, articulation and chains of equivalence explain how social movements coordinate diverse struggles against hegemonic relations of power.

Although articulation is often associated with the linkage of demands into chains of equivalence, McKibben's rhetoric suggests that chains of equivalence also can be built by linking gestures. Two chains of equivalence are especially significant in McKibben's articulation of climate-related gestures. First, he links seemingly individualistic acts of consumption with collective political activity ${ }^{5}$. For example, in the quote from the Lannan speech above, McKibben compares the gesture of a new solar rooftop to that of a divested college or "even a strong, beautiful movement for [divestment]." In doing so, McKibben not only interpellates individual consumers as part of a collective political struggle, "the fossil fuel resistance," but also calls attention to the political struggles that are necessary to enable such consumer choices. For example, when accused of not doing enough to support renewable energy policies by a questioner at Columbia University, McKibben folds that work into the "silver buckshot" analogy: "And the part you're talking about [creating policy] is an important part, and a part that people are deeply engaged in all throughout the country that I know of, certainly, every place I go" (McKibben, 2013b).

Second, McKibben articulates gestures to help his audience understand that although each gesture has a unique context, together they represent a global movement constituted in solidarity. For example, in the Lannan speech (McKibben, 2015a), he describes the Cowboy/Indian alliance, an action in which ranchers, farmers, and tribal communities joined together in Washington, DC, to protest the Keystone XL Pipeline. He encourages his audience to "[t]hink of the power of that gesture with the sort of two of the great romantic, um, um, forces in American history, no longer in opposition but together" (McKibben, 2015a). He also links divestment campaigns at Harvard, Stanford, the University of the Marshall Islands, and Swarthmore, the 2014 People's Climate March, the blockade of the world's largest coal port in New Castle, Australia, and Pope Francis' "soon-to-be-released" encyclical on the environment as akin to a "series of gestures with which his papacy has, um, unfolded. Kneeling down to kiss the feet of prisoners... Out amongst the poorest, um, much as he can be" (McKibben, 2015a). Here he calls upon his audience to see this "series of gestures" as "helping people re-discover some sense of solidarity with the rest of the world." He describes organizing senior citizens to engage in civil disobedience to stop the Keystone XL pipeline, and provides the following illustration of an individual act from that event: "And on the last day there was a guy arrested with a sign around his neck that said, "World War II vet, handle with care"' (McKibben, 2015a).

McKibben's articulation of gestures creates a chain of equivalence across a wide geographic and demographic terrain, constituting solidarity amongst diverse activists around the world. Such a perspective resonates with Robert Asen's (2017) discussion of "the prospects for resistance to a neoliberal public through the coordinated action of networked locals" (p. 3). From "Cowboys" and "Indians" to Harvard and the Pacific Islands, McKibben links locals and their gestures in a chain of equivalence, describing the fossil fuel resistance as "spreading

\footnotetext{
${ }^{5}$ In other texts McKibben dismisses individualistic gestures such as installing solar panels or driving a "plug in car" as individualistic gestures incapable of solving the climate crisis. However, he also notes that most people who do those things are also involved in the climate movement. Ultimately, he consistently argues that collective action is the only way to address the climate crisis: "What can I do?" is the wrong question, he argues. Instead, one should ask: "What can we do?" See for example: https://www.ecowatch.com/bill-mckibben-climate-change-2041759425. html
} 
in every direction around the world, almost as sprawling and protean in its form as the fossil fuel industry itself" (McKibben, 2015a). Although McKibben articulates diverse gestures as comprising the fossil fuel resistance, he does not deny the uniqueness of each gesture. They remain distinct, but the gestures operate together, constituting a movement based on "opensource organizing” in dispersed locales. As McKibben explains with regard to the divestment movement, "everybody knows, in their own place, how best to do it" (McKibben, 2015a), (see also Sprain et al., 2009).

Each gesture may be vulnerable to critics' claims of it being fanciful, utopian, idealistic, individualist, self-serving or irrational. But McKibben does not leave them as isolated acts to be evaluated in their singularity. He piles up gestures to direct audience attention toward a new future, one that is not dictated by fossil fuel companies, but by the goal-driven actions of diverse organizations and individuals.

\section{Interrupting Inevitability, Enacting a New Future}

Critical theorists have long noted that bodily gestures do more than provide semiotic content; they are also the site or "citations" of culture, discipline, and power on the body. From Walter Benjamin's (1968) analysis of Brecht's epic theater to Judith Butler's (1990) explication of performative bodies, theorists have established the power of gestures to interrupt the commonplace. "Interrupting gestures," Benjamin argues, "alienate" audiences from the existing "conditions of life" (p. 150). Similarly, Massumi (2015) contends that "resistance is of the nature of a gesture" (p. 105). In McKibben's rhetoric, gestures are capable of puncturing the illusion of a preordained future underwritten by fossil fuels. For McKibben, the carbon economy is not simply a brute fact of infrastructure, but rather a relentlessly rhetorical effort to shape public perception of the way things are and always will be, an ideology - a set of beliefs that naturalize a particular set of market and social relations:

The battle, in the end, in this case, is for control of the zeitgeist, for control of how we think about the world, okay? Our sense of what is going to happen. And the other side understands that exquisitely. It's why the fossil fuel industry spends all their time trying to promote the inevitability of continuing down the current path.

(McKibben, 2015a)

McKibben uses gestures to challenge that sense of inevitability. He interprets actions that run counter to the business-asusual path as gestures that confound this commonsense. "Each time a gesture is made...that sense of what's going to happen begins to shift" (McKibben, 2015a; emphasis added). Multiple gestures build on one another to create a sense of movement and momentum that belies the fossil fuel industry's rhetoric of certitude. McKibben continues, "There's an almost mathematical sense of, of, of, gestures piling up on one side or the other, giving strength to one side or the other" (McKibben, 2015a).

McKibben's use of gesture is consistent with Massumi's emphasis on gesture as enactment. When he claims that resistance is gestured into existence and functions as immanent critique, he is suggesting that the exemplary power of gestures enacts alternative modes of engaging the world and invites others to participate, paradoxically altering the course of inevitability. For example, McKibben interprets the Rockefeller family's decision to divest from fossil fuels on the eve of the first People's Climate March as unique, but also as exemplary, as symbolic of an imminent cultural shift:

But just think about what that means. That the first great fossil fuel fortune had now recognized that the moment had come to switch, and the power of that was palpable. Um, it was the beginning of the end of the fossil fuel age that day, between that huge march and that announcement, and the question only is how quickly, how quickly we will make that end come, and whether it will come in time $e^{6}$.

(McKibben, 2015d)

This "palpable” switch resonates with Massumi's (2015) reference to C.S. Peirce's notion of "abduction," or, "thought that is still couched in bodily feeling" to explain the exemplary power of gesture (p. 9-10). Massumi argues gestures of resistance "are thought in the immediacy of enactment," which elicit affective response in conjunction with thought (p. 207). This way of considering gestures is consistent with the affective, contagionlike approach that Hawhee interprets in Paget, a theory that "figures speech as a bodily, mimetic, even affective art, thereby imagining bodily feeling, gesture, and posture as unconsciously contagious and iterable movements" (Hawhee, 2006, p. 336).

This affective quality of gestures, as communicable thinkingfeelings in the process of becoming, means that gestures of resistance do not exactly make arguments for an alternative future; rather, they enact different ways of relating and orienting to the world, and thus gesture toward an alternative future. In envisioning a new future for the planet, McKibben differentiates between the vision put forth by the fossil fuel industry and the one that must be called forth by climate activists. "Their job is to make the status quo seem inevitable; our job is to the make the future, the change seem inevitable, and possible, and to get there. Creativity is the absolute most important thing in this fight" (McKibben, 2015a). In turn, McKibben emphasizes that "proper gestures, good gestures" are "beautiful, artistic moments" that enable "you to see behind them powerful truths" (McKibben, 2015a). For example, with respect to renewable energy, his alternative future integrates the material realities of innovation and engineering with romantic notions of beauty:

The engineers allow us to imagine; if the scientists tell us that we need a fossil freeze, the engineers allow us to imagine a solar farm, and also wind power and the other things that come quickly with it. But to imagine a solar farm, to imagine in the process of doing that, not just a world that might be able to keep from going over, but, but also a world that might work in many ways much more beautifully than the one we live on now.

(McKibben, 2015a)

Part of the beauty of this future is that it is more equitable, as power shifts from fossil fuels which divert wealth into the hands

${ }^{6}$ This speech was given in Paris on the eve of the Paris Climate Accords meeting. We include it because its audience incudes members of the US. 
of a few, to a system of energy that rebalances power because of the diffusion of the sun and the wind:

That's the beginning of a different kind of world. So there is real possibility here. A glimmer of possibility. The fortifying thing, given that glimmer, is to see how little we are doing given that maybe an ember is the right, um, message, is the right image, to see how little we are doing to, to blow it into life, to make it spark, to make it spread, to make it blaze, to make it blow up into something big enough to light the world.

(McKibben, 2015a)

This vision may be fodder for criticisms such as Nisbet'sthat McKibben relies too heavily on symbolic acts of resistance and romantic and utopian visions of the future. However, these criticisms fail to consider two things. First, that a utopian impulse plays an important role in social movement rhetoric enabling both a reconstructive vision and a reconstructive praxis. In this regard a utopian impulse includes both "critique of existing conditions and a vision of a reconstructed program for a new society" (Dan Chodorkoff, 1983, see also Jameson, 1981). This reconstructive vision need not be limited to literary and philosophical blueprints; when it takes the form of a social movement, it can function as a praxis for concrete social change. Gestures for McKibben, then, function as both immanent critique and indexes of an unfolding inevitable social change, and as a vision for what that change can bring. Second, critiques of McKibben's utopian impulse fail to consider the "pragmatic capacities" of gestures to leverage systems to "achieve tangible effects" (Foust, 2017, p. 65).

\section{Leveraging Systems}

According to Mohan Dutta (2011), "the performance of social change is fundamentally directed at articulating change through the disruption of structures" (p. 212). Strategic gestures can enable such articulations. To the extent that gestures are composed with an eye toward vulnerabilities and opportunities within systems of power, they can leverage systemic change. From this perspective, gestures become increasingly strategic as they locate sites for applying leverage to alter a system.

In his speeches and during question and answer periods, McKibben justifies several "symbolic" climate actions by arguing that such gestures are also material interventions intended to alter economic systems or apply political pressure. When one audience member asks him to explain how symbolic gestures are going to create "real" material change, McKibben (2015a) dismantles that distinction: "So let's look at Keystone as an example. It is a symbol, but it's only an effective symbol because it is real, okay?" As a result of the delays created by the campaigns to stop the pipelines, "They're already falling into huge difficulty; the expansion plans to triple and quadruple the draw in the tar sands" is "not gonna happen" (McKibben, 2015a). Similarly, when addressing Seattle "kayaktivists" who banded together to blockade fossil fuel infrastructure from leaving port, McKibben (2016b) refers to related efforts in nearby communities as taking advantage of "choke points by which we can stick a cork in the fossil fuel bottle. ... If they don't, can't build the port at Cherry
Point, and they can't build the port at Longview, then they're not gonna mine the coal in Montana and Wyoming. It's gonna stay underground, alright?"

McKibben's “choke points" discussion mirrors Cox's analysis of the Sierra Club's Beyond Coal campaign, in which he describes the strategic in terms of applying leverage at local sites of decision in order to alter systems of power. For Cox (2010), this requires that a campaign create "strategic alignment of mobilization and its mode of influence or leverage that can enable wider outcomes or effects" (p. 128). These effects do more than disrupt structures and systems; they literally alter them. Project delays and denied permits are not only symbolic victories, which open space for articulation as Dutta suggests; they also have material, economic effects by producing signals in financial markets to shift investment to renewable energy. Such shifts can reduce the power of the fossil fuel industry and enable more alterations to the built environment that can further influence perceptions of inevitability.

Gestures also provide activists with opportunities to articulate policy agendas and apply leverage in transformed arenas of political discourse. Explaining how the divestment movement successfully influences public discourse, McKibben (2016b) avers: "And now it's not, you know, me in Rolling Stone. Now it's the head of the IMF, the head of the World Bank. It was the head of the Bank of England talking to the world's insurance industry" about the fact that they are "overexposed to what are going to be stranded assets from a carbon bubble." Strategic gestures can intervene in systems of power by altering the symbolic field and reaching new audiences. McKibben identifies this function of gestures with respect to divestment. "If we can continue this divestment fight, we can call it symbolic if you want, but its huge effect has been to make it far more difficult for people to raise capital to do what they're gonna do" (McKibben, 2015a). Here McKibben effectively dissolves the symbolic/material distinction by positioning divestment as a gesture that has both symbolic and material effects.

In this way, gestures contribute to a strategy for social change that aligns with time-honored functionalist approaches to social movement organization and resource mobilization (Simons, 1970): a strategy designed to bring the other side to the bargaining table. For example, McKibben explains how the piling up of gestures can create conditions that are amenable to policy changes:

We're going to have to impose that [carbon] tax in all the ways we can by making it difficult for business as usual to go on. And when we break their power some, then we'll get some kind of carbon tax, you know. They'll start to sue for peace, and we'll see what happens, but in the meantime that's our job. Their job is to make the status quo seem inevitable, our job is to make the future, the change seem inevitable, and possible and to get there.

(McKibben, 2015a)

Gestures can be strategic, then, to the extent that they integrate efforts at ideological transformation with opportunistic intervention in political and economic systems. In McKibben's (2015a) words, "You want to pick things that have real outcome, and that'll also produce this change in the sense of inevitability, 
and the zeitgeist, because, you know, control of the zeitgeist is an important asset. It's, you know, in some ways the most important asset."

\section{PRACTICAL IMPLICATIONS}

To this point we have argued that strategic gestures can have multiple rhetorical effects. But do such gestures “work?" Under what conditions might strategic gestures be more likely to achieve the kinds of effects that McKibben describes? Some observers have already posed such questions in relation to McKibben's work, specifically with respect to divestment. As Schneider et al. (2016) have argued, "The rhetorical power of divestment, therefore, lies in the movement's ability to change the terms of public discourse about fossil fuel production and incite more discourse about climate change from new and potentially powerful rhetorical audiences" (Schneider et al., p. 122). This argument is bolstered by Schifeling and Hoffman's (2017) research which demonstrates that McKibben and 350.org's divestment campaign "expanded the spectrum of the climate change debate and shifted its central focus" via a "radical flank effect," whereby radical issues enter into a polarized and seemingly intractable debate to disrupt the field of discourse enabling "previously marginalized liberal policy ideas such as a carbon tax and carbon budget to gain greater traction in the debate" (p. 16).

However, our explanation of strategic gestures suggests a more complex account and a more mixed evaluation of the apparent "success" of the divestment campaign. On one hand, divestment activism may have disrupted the prevailing common sense on climate change, reconfigured relationships between activists and financial firms and investors, and created discursive space for discussing a carbon tax. McKibben (2016c) himself understands gestures as creating that space, and he sees such a tax as a necessary but not sufficient gesture toward an alternative future. At the same time, these productive interventions in "the zeitgeist" do not necessarily ensure policy victories, and the jury is still out as to whether the campaign will achieve the same success as other divestment campaigns, such as those around tobacco and South African apartheid.

More broadly, it is worth considering how an assemblage of strategic gestures might influence climate politics under a radically different US presidential administration. Regulatory rollbacks, the withdrawal from the Paris Agreement, and the gutting of agencies focused on climate change all interrupt McKibben's buoyant rhetoric of inevitability. This elevates a potential tension between the locus of inevitability that is so central to McKibben's rhetoric, and the locus of the irreparable that is one of Cox's significant contributions to the study of environmental communication (Cox, 1982). For instance, it would be easy for activists today to despair of the rapid dismantling of climate research and Obama-era climate regulations under President Trump's administration, question McKibben's utopian invocations of inevitability, and embrace apocalyptic rhetoric that urges audiences to take extraordinary measures to forestall loss. The latter could be persuasive for McKibben's choir and the $21 \%$ of US residents who occupy the "Alarmed" category in Yale's Six Americas research as of March
2018 - the largest proportion in the history of that survey (Yale Program on Climate Change Communication, 2018). The blithe dismissal of the climate challenge by the Trump administration creates a situation that is ripe for appeals to the irreparable.

Alternatively, despairing activists could resign themselves to the inevitably of climate change, or conclude that the only options available are litigation and procedural maneuvers to forestall and limit the damage until circumstances change. Yet McKibben's rhetoric of inevitability may offer an alternative whose time has come. Like apocalyptic rhetorics that warn of imminent disaster, McKibben's invocations of inevitability "are not to be taken literally. Their aim is not to predict the future but to change it" (Killingsworth and Palmer, 1996, p. 41). From this perspective, setbacks and reversals do not disprove McKibben's rhetoric of inevitability. Rather, they heighten the paradox that inevitability is contingent; the future is dependent on human action. Like any social movement, "Which future ultimately comes about ... will depend on the 'people' and their collective actions" (Stewart et al., 2007, p. 55). Indeed, shortly after the 2016 election McKibben (2017) reiterated his call for a battle for control of the zeitgeist. "In the end," he argued, "the real fight is not over a pipeline or a windmill or even a carbon tax. The real fight-all real fightsare over the zeitgeist. They're about who controls the vision of the future."

Strategic gestures are central to this vision in at least two key ways. First, strategic gestures can pinpoint crucial sites of leverage where systems can be turned against themselves or steered in a more favorable direction. The climate movement recognized the limits of Federal action well before the 2016 election and directed public pressure on states and cities, in addition to targeting fossil fuel investments and infrastructure. In February of 2018 McKibben, once again assembling disparate elements of the climate movement, articulated a Fossil Free US campaign. Its three elements included: 1 . Joining the Sierra Club's "Ready for 100 " campaign to work at the state and local level; 2. Continuing to block the development of fossil fuel infrastructure; and 3. Cutting off the money that fuels the industry through divestment and lawsuits (McKibben, 2018).

The Sierra Club's "Ready for 100" campaign provides a useful case study of the relevance of strategic gestures in a political landscape altered by the Trump presidency. The campaign persuades local and state governments to pledge to transition to $100 \%$ renewable energy by a particular date (usually 2035 or 2050). Similar campaigns have targeted businesses and organizations such as universities. While these pledges have been criticized as little more than symbolic gestures, with one critic referring to them as "misleading and silly" (McConnell, 2017, see also Fisher, 2015; Roberts, 2017), they are nonetheless strategic gestures with the capacity to alter economic, political, and ideological systems. Local governments as sites of decision making are strategic sites for the application of leverage. Commitments to use renewable energy produce more demand for it, which sends market signals and alters the economic system. Further, each pledge is a victory for the climate movement, producing momentum and movement toward an inevitable future and a new zeitgeist. In this regard, strategic gestures like these are like bodily gestures that "catch-on." They are both communicable and communal. This momentum of 
victories is further amplified by market changes-literally the increasing presence of renewable energy infrastructure is both evidence of an ongoing transition and productive of the felt experience of "change in the air."

This gestural momentum enables rhetors, like Van Horn (2018) the Sierra Club's "Ready for 100" campaign director, to invoke the locus of the inevitable. To do so, she both assembles a piling up of gestures, "From big cities like Atlanta and San Diego to small towns like Abita Springs, LA and Hanover N.H., cities are switching to 100 percent clean energy," and articulates solidarity across difference "More than 150 mayors, Democrats and Republicans, have also pledged to power their cities with renewable energy." To this she adds that "more than 100 companies have also pledged to source 100 percent of their energy from renewables, including Apple, General Motors, Walmart, and Johnson \& Johnson." These tropes of momentum and solidarity enable Van Horn to situate her audience as already living in the time of transition. As she constructs it, the only contingency is whether it will be a fair and just transition: "As the transition away from dirty fuels continues to take shape across the country, it's up to all of us to determine what a true clean energy economy looks like, who benefits from it, and how we will get there in a way that empowers everyone in our communities."

The second reason that strategic gestures are central to building an alternative future is that they connect these pragmatic interventions to visions of the future grounded in new relationships and identities, which are needed to alter the political conditions that can make other kinds of interventions possible. The initial response of critics like Nisbet (2013) to McKibben's climate change rhetoric was that it was polarizing and would not appeal to mainstream audiences. This, it was argued, would all but destroy the possibility for bipartisanship and legislative compromise. Whether or not such compromise was possible is debatable (Nisbet, 2018; Roberts, 2019; Taylor, 2019) ${ }^{7}$. Yet, by 2019, Nisbet himself declared that the battle for public opinion on climate change was over, "The decades-long struggle by scientists and environmentalists to build broad-based support for cutting greenhouse emissions is finally over. Science has won" (Nisbet, 2019). Nonetheless, he warned that the ambitious and potentially-polarizing rhetoric of McKibben and Green New Deal advocates Rep. Alexandria Ocasio-Cortez and Sen. Ed Markey would once again prevent bipartisan legislative action. This is because "galvanized public opinion is not sufficient. History suggests that shifts in polling and the rise of mass movements are at best only able to create windows of opportunity for policy change to happen," and these windows must be navigated carefully (Nisbet, 2019). Thus, Nisbet once again counseled "a pivot toward policy pragmatism" (Nisbet, 2019).

\footnotetext{
${ }^{7}$ Nisbet provides many examples of the kinds of compromise he believed were possible, such as policies that would have sparked greater innovation in renewables, carbon capture and sequestration technologies, and nuclear power. Many of these did become policy during the Obama and Trump Administrations, such as Tax Credits for renewable energy. Whether larger initiatives could have been cobbled together is questionable. Even if they would have been possible, they would have required compromise from climate activists on core values, which is akin to demanding that climate deniers simply change their stance.
}

But what is "pragmatism?" McKibben's approach to movement building and climate change rhetoric certainly deserves much of the credit for the dramatic shift in public opinion and the reorganization of the discursive field of climate change politics. This is a field in which cap and trade policy proposals of the Waxman-Markey variety and Tax and Dividend proposals long championed by the Citizen's Climate Lobby and the Climate Leadership Council now appear to sit squarely in the middle between a Green New Deal on the left and a variety of proposals offered from the right such as Rep. Matt Gaetz's "Green Real Deal" and Sen. Lamar Alexander's call for a "New Manhattan Project for Clean Energy" (Waldman and Matthews, 2019). The extent to which these changes will be enough to get the fossil fuel industry to "sue for peace," as McKibben puts it, is uncertain. Nonetheless, they serve as evidence that McKibben's approach to climate change rhetoric and the use of strategic gestures are not without merit.

Politics and policy are different but equally important. Critics like Nisbet tend to focus on policy pragmatism in a relatively narrow purview, which focuses on the field of politics as it is: adapting policy and rhetorical invention to circumstances as they find them. In contrast, activists like McKibben are searching for ways to rearrange and reconstitute the context of politics in which policy negotiation can take place. As political scientist Skocpol (2013) writes in her diagnosis of the failure of cap and trade legislation in 2010:

Climate change warriors will have to look beyond elite maneuvers and find ways to address the values and interests of tens of millions of U.S. citizens. To counter fierce political opposition, reformers will have to build organizational networks across the country, and they will need to orchestrate sustained political efforts that stretch far beyond friendly Congressional offices, comfy board rooms, and posh retreats. Compromises with amenable business interests will still be necessary. But insider politics cannot carry the day on its own, apart from a broader movement pressing politicians for change. (p. 11)

From this perspective, strategic gestures can be seen as a vital means for movement activists and policy entrepreneurs to coordinate efforts to increase public pressure for climate action. It is necessary in order to create the conditions in which different kinds of policy compromises can be pursued and better deals can be made. McKibben and other climate activists need to address the values and interests of ordinary citizens and be prepared to make deals when the windows of opportunity open; but at the same time, policy reformers will need to give greater credence to the necessary role that grassroots mobilization plays in achieving their goals.

\section{THEORETICAL IMPLICATIONS}

Our conception of strategic gestures weds existing accounts of the communicative, performative, and affective aspects of symbolic action with considerations of "the strategic" as outlined by Cox in order to advance a theory of social change that is greater than the sum of its parts: symbolic acts of resistance 
complementing and amplifying systemic interventions, and those interventions leading to new types of symbolic action that promote solidarity and offer new visions of the future. In this way, strategic gestures can engage the "complex whole" of economic, political, and ideological systems that need to be transformed in order to effectively address climate change. This theorization of strategic gestures extends several scholarly conversations in environmental communication and rhetorical studies more generally.

First, this analysis extends and complicates Cox's attempts to revive "the strategic" as a central consideration in social movement rhetoric. His approach enables critics and activists to think about the purpose of social movement rhetoric as something more than producing a "message that cannot be ignored (Cox, 2009, p. 409-410)." However, it also tends to characterize communication as the sending of signals in a network of relations. This downplays the ways that rhetoric can transform perception and opinion, and the effects these can have on the transformation of complex systems. Our analysis of strategic gestures acknowledges the fact that complex systems are irreducible - that economic, political, and ideological systems are inextricably bound together-and thus that transformation of those systems requires rhetorical interventions that have symbolic and ideological force in addition to their capacity to send signals within economic systems. To be clear, not every gesture described by McKibben qualifies as a "strategic" intervention; divestment campaigns and efforts to block pipelines certainly do, while others, like driving an electric car, may only become strategic to the extent that they get articulated to larger patterns of symbolic and material change. The concept of strategic gestures enables this distinction and illuminates how gestures can promote social transformation, not just resistance.

Second, the concept of strategic gestures broadens the domain of symbolic actions in several ways. On one level, our analysis points to the gestural as a significant category of symbolic action beyond the verbal/visual binary that has been central to the emergence of visual rhetoric as an area of inquiry ${ }^{8}$. This expansion becomes important as environmental communication scholarship moves beyond image-focused analyses of hypermediated environments to new materialist approaches that consider how the built and mediated environments commingle. In other words, critical attention need not be limited to events and acts of resistance that are tailored to media logics (image events, spectacle) or which produce meaning though drama (protest, confrontation). Critical attention can also focus on material aspects of daily lived experience, such as transformations in the built environment. The ever-increasing presence of solar panels and wind power, for example, enact change and provide a reconstituted vision of the future. In addition, strategic gestures invite critics to focus attention on the variety of ways in which

\footnotetext{
${ }^{8}$ For example, in a recent essay with Brunner, DeLuca continues to characterize the symbolic universe within a word/image problematic: "Even if images are always in the world of words, still, the force of images may transgress the limits of textual representation and interpretation. The capacity to transgress textual representations points to the event quality of images. Images are not subsumable to language because the two are fundamentally distinct" (Brunner and DeLuca, 2016, p. 294).
}

gestures build one upon another to produce meanings, affects and effects. Strategic gestures do more than represent an argument, an ideal, or an idea; they also display, transform, and provide opportunities for further articulation.

Third, strategic gestures can be a productive mode for enabling networked publics and generating counterpublicity. As Asen (2017) indicates, "Beyond deliberation, people may employ various forms of rhetoric and communication to recognize mutual standing and facilitate coordinated action. Perhaps through creativity born of struggle, counterpublicity may lend itself to discursive innovation" (p. 5). Strategic gestures can be considered a discursive innovation that is oriented not toward deliberation, but toward articulation and mobilization of loosely networked local publics. McKibben's notion of opensource organizing reflects this orientation toward networked publics, as does Klein's (2014) notion of "Blockadia" as "a roving transnational conflict zone that is cropping up with increasing frequency and intensity wherever extractive projects are attempting to dig and drill” (p. 294). To the extent that strategic gestures intervene locally and resonate globally, they open possibilities for new forms of solidarity. This echoes Asen's claims that, "Drawing on the mobility, flexibility, and generativity of interactions in a network, a resurgent critical publicity may emerge through new and reconfigured sites of engagement and human relationships" (p. 13).

Fourth, our analysis shows how a politics of gesture can clarify what is meant by "impure politics." Referencing Lawrence Grossberg, Pezzullo (2011) explains that because there is no "pure political choice outside the systems we wish to challenge," there is a need for "contingent and pragmatic practices of social change" (p. 127). Pezzullo's work reminds us to account for the contingent relationships between symbolic and material change, and to pay attention to the constitutive and mobilizing value of symbolic targets and their contribution to the application of leverage at local sites of decision-making. Organizing to stop a pipeline such as Keystone XL is not "merely" symbolic. It provides a movement with opportunities for organizing and getting more people involved in a movement; it can provide activists with opportunities to challenge perceptions of inevitability and gesture toward an alternative future; and it can function as an intervention that can upend economic and political relations of power.

From this perspective, differences over pure and impure politics appear to hinge on differing ideas about what counts as a "pragmatic" practice of social change. Nisbet's criticism of McKibben, for example, seems to position the latter as a purist who takes "no compromise," "line-in-the-sand" stances on issues, tends to "double-down" on his approach in the face of setbacks, and has "little tolerance for political pragmatism" (Nisbet, 2013, p. 50, 52). But from a broader viewpoint, McKibben's attention to gestures is an eminently practical maneuver to transform the discursive field and open up new sites of leverage in the face of recalcitrance and half-measures at the federal level, whereas for Nisbet, pragmatism appears to mean environmentalists compromising with Republicans and moderate Democrats to pass incremental policy reforms. Our theorization of strategic gestures underscores how the limited notion of pragmatism 
presumed by critics such as Nisbet entails a rather cramped politics, one that conflates politics with policy and is blind to how rhetoric functions as a pragmatic art.

\section{CONCLUSION}

With this essay, we have intended to help environmental communication scholars and advocates observe the "messy environmental, economic, moral, ethical, political, and symbolic dynamics" of strategic gestures and how they communicate "much more than what might be immediately apparent" (Pezzullo, 2011, p. 140). McKibben's turn toward gestures as a crucial component of climate activism reminds us that neither rhetoric nor social movements are concerned solely with what is actual. The province of both is the realm of the possible, of moving people from their current situation to that which is yet to be (Poulakos, 1983). Strategic gestures may ground themselves in the actual, yet their potency lies in how they display and produce for their audiences a world in the process of becoming otherwise.

\section{REFERENCES}

Asen, R. (2017). Neoliberalism, the public sphere, and a public good. Q. J. Speech 103, 329-349. doi: 10.1080/00335630.2017.13 60507

Benjamin, W. (1968). "What is epic theater?" in Illuminations, transl. by H. Zohn. New York, NY: Schocken Books, 147-154.

Bronstein, Z. (2014). Bill McKibben's Difficult Political Education. Dissent. Available online at: http://zeldabronstein.com/bill-mckibbens-difficultpolitical-education/ (accessed August 14, 2018).

Brulle, R. J. (2010). From environmental campaigns to advancing the public dialog: environmental communication for civic engagement. Environ. Commun. 4, 82-98. doi: 10.1080/17524030903522397

Brunner, E., and DeLuca, K. (2016). The argumentative force of image networks: Greenpeace's panmediated global detox campaign. Argument. Advoc. 52, 281-299. doi: 10.1080/00028533.2016.118 21875

Butler, J. (1990). Gender Trouble: Feminism and the Subversion of Identity. New York, NY: Routledge.

Caldwell, C. (2005, January 23). The triumph of gesture politics. The New York Times. Available online at: https:/www.nytimes.com/2005/01/23/magazine/ the-triumph-of-gesture-politics.html (accessed August 14, 2018).

Chodorkoff, D. (1983). The utopian impulse: reflections on a Tradition. Harbinger 1, 1. Available online at: http://social-ecology.org/wp/1983/12/the-utopianimpulse-reflections-on-a-tradition/ (accessed November 9, 2018).

Cox, J. R. (1982). The die is cast: topical and ontological dimensions of the Locus of the irreparable. Q. J. Speech 68, 227-239.

Cox, J. R. (2009). "SIU and beyond: challenges of scale and the strategic," in Social Movement to Address Climate Change: Local Steps for Global Action, eds D. Endres, L. Sprain, and T. R. Peterson (Amherst, MA; New York, NY: Cambria Press), 393-422.

Cox, J. R. (2010). Beyond frames: recovering the strategic in climate communication. Environ. Commun. 4, 122-133. doi: 10.1080/ 17524030903516555

DeLuca, K. (1999). Image Politics: The New Rhetoric of Environmental Activism. Mahwah, NJ: Lawrence Erlbaum Associates, Inc.

Dutta, M. (2011). Communicating Social Change: Structure, Culture, and Agency London: Routledge.

Eckersley, R. (2005). Translating science and restoring our sense of wonder. Org. Environ. 18, 193-197.

Endres, D., Sprain, L., and Peterson, T. (2008). The imperative of praxisbased environmental communication research: suggestions from Step

\section{DATA AVAILABILITY}

All datasets analyzed for this study are included in the manuscript and/or the supplementary material.

\section{AUTHOR CONTRIBUTIONS}

Each author contributed substantially to the ideas and text of this paper. The authors order indicates our assessment of the relative contribution of each author.

\section{ACKNOWLEDGMENTS}

The authors would like to thank the editor and reviewers for their helpful suggestions and guidance. They would also like to thank J. Robert Cox and Katey Castellano for their encouragement and insightful comments on earlier drafts of this article. A Provost's Summer Research Grant from James Madison University was instrumental to the completion of this project. The authors are grateful to Daniel Vieth for his transcription services and labor.

It Up 2007 national research project. Environ. Commun. 2, 237-245. doi: 10.1080/17524030802141794

Endres, D., Sprain, L., and Peterson, T. R. (2009) Social Movement to Address Climate Change: Local Steps for Global Action. Amherst, MA; New York: Cambria Press.

Engler, M., and Engler, P. (2013). Climate of change: what does an inside-outside strategy mean? Dissent. Available online at: https://www.dissentmagazine. org/article/climate- of-change- what-does-an-inside- outside-strategy-mean (accessed April 14, 2017).

Fisher, T. (2015). Busting the "100 Percent Renewable" Myth. Institute for Energy Research. Available online at: https://www.instituteforenergyresearch.org/ renewable/wind/busting-the-100-percent-renewable-myth/ (accessed March $25,2015)$.

Foust, C. (2017). "Social movement rhetoric: a critical genealogy, post-1980," in What Democracy Looks Like: The Rhetoric of Social Movements and Counterpublics, eds C. R. Foust, A. Pason, and K. Z. Rogness (Tuscaloosa, AL: University of Alabama Press), 46-75.

Goldenberg, S. (2014, December 3). Keystone XL opponent Bill McKibben steps down as head of 350.org. The Guardian. Available online at: https:// www.theguardian.com/environment/2014/dec/03/keystone-xl-opponent-billmckibben-steps-down-as-head-of-350org

Greene, R. W. (1998). Another materialist rhetoric. Critic. Stud. Mass Commun. 15, 21-40. doi: 10.1080/152950398093 67031

Hariman, R. (1992). Decorum, power, and the courtly style. Q. J. Speech 78, 149-172. doi: 10.1080/003356392093 83987

Hawhee, D. (2006). Language as sensuous action: Sir Richard Paget, Kenneth Burke, and Gesture-Speech theory. Q. J. Speech 92, 331-354. doi: 10.1080/00335630601080393

Hazan, L., Cadan, Y, Brooks, R. Rafalowicz, A., and Fleishman. 1000 Divestment Commitments and Counting. Fossil Free. Available online at: https:// gofossilfree.org/wp-content/uploads/2018/12/1000divest-WEB-.pdf (accessed May 30, 2019).

Hertsgaard, M. (2014, December 9). How 350.org is (still) changing the climate justice movement. The Nation. Available online at: https://www.thenation. com/article/how-350org-still-changing-climate-justice-movement/ (accessed August 14, 2018).

Holding, C. (2015). The rhetoric of the open fist. Rhetoric Soc. Q. 45, 399-419. doi: 10.1080/02773945.2015.1058973

Jameson, F. (1981). The Political Unconscious: Narrative as Socially Symbolic Act. Ithica, NY: Cornell University Press. 
Killingsworth, M. J., and Palmer, J. (1996). "Millienial ecology: the apocalyptic narrative from Silent Spring to Global Warming," in Green Culture: Environmental Rhetoric in Contemporary America, eds C. G. Herndl and S. C. Brown (Madison, WI. University of Wisconsin Press), 21-45.

Klein, N. (2014). This Changes Everything: Capitalism Versus the Climate. New York, NY: Simon \& Schuster.

Laclau, E., and Mouffe, C. (1985). Hegemony and Socialist Strategy: Towards a Radical Democratic Politics. London: Verso.

Luke, T. (2005). Collective action and the eco subpolitical: revisiting Bill McKibben and the end of nature. Org. Environ. 18, 202-206. doi: $10.1177 / 1086026605276014$

Massumi, B. (2015). The Politics of Affect. Cambridge: Polity Press.

McConnell, C. (2017, August 4). City pledges for "100\% renewable energy" are $99 \%$ misleading. Wall Street Journal. Available online at: https://www. wsj.com/articles/city-pledges-for-100-renewable-energy-are-99-misleading$1501888640 ?$ mc_cid $=18$ ed 91 d $8268 m c \_e i d=2 b 590 a 0$ e65

McKibben, B. (2012, August 2). Global warming's terrifying new math. Rolling Stone. Available online at: https:/www.rollingstone.com/politics/ politics-news/global-warmings-terrifying-new-math-188550/ (accessed July 24, 2019).

McKibben, B. (2013a). Oil and Honey: The Education of an Unlikely Activist. New York, NY: Macmillan.

McKibben, B. (2013b). Report from the Frontline of Climate Change. Speech, the Hertog Global Strategy Initiative in the Department of History, Columbia University, New York, NY. Available online at: https://youtu.be/ u1NUZDqKyuk (accessed April 15, 2016).

McKibben, B. (2015a). "The End of Nature' a quarter century after. Keynote Address of the Lannan Symposium," in Nature's Wake: The Art and Politics of Environmental Crisis (Washington, DC: Georgetown University). Available online at https://youtu.be/yIf_DlThSio (accessed April 12, 2016).

McKibben, B. (2015b). "From evidence to action: we are ALL activists now," in Speech, Meeting the Challenge of Climate Justice: From Evidence to Action Conference (National University of Ireland, Maynooth University). Available online at: https://www.youtube.com/watch?v=yzbcwmxktzs\&feature=youtu.be (accessed September 26, 2016).

McKibben, B. (2015c). Panel presentation. Off + On: The Climate Movement + the Road Through Paris. Brooklyn, NY. Available online at: https://youtu.be/ eq8vb6E9sO0 (accessed September 3, 2016).

McKibben, B. (2015d). "Keynote speech, Stop financing fossil fuels; Fight climate change," International Conference on Divestment, Maison de la Chimie (Paris). Available online at: https://youtu.be/1vnQIYlyCA4 (accessed September 25, 2016).

McKibben, B. (2016a, August 31). Walk of Ages: How a Vermont March Helped Launch a Climate Movement. Seven Days: Vermont's Independent Voice. Available online at http://www.sevendaysvt.com/vermont/walk-of-ageshow-a-vermont-march-helped-launch-a-climate-movement/Content?oid= 3633748 (accessed April 14, 2017).

McKibben, B. (2016b). Breaking Free From Fossil Fuels. Speech, Town Hall Seattle. Seattle, WA. Available online at: https://www.youtube.com/watch?v= Pz490L3EWmM\&feature=youtu.be (accessed April 4, 2016).

McKibben, B. (2016c, September 12). Why we need a carbon tax, and why it won't be enough. Yale Environment 360. Available online at: https://e360. yale.edu/features/why_we_need_a_carbon_tax_and_why_it_won_be_enough (accessed August 14, 2018).

McKibben, B. (2017, January 23). With the rise of Trump, Is it game over for the climate fight? Yale Environment 360. Available online at: https://e360.yale.edu/ features/with-the-ascent-of-trump-is-it-game- over-for-the-climate-fight (accessed January 30, 2017).

McKibben, B. (2018, February 1). We can battle climate change without Washington DC: Here's how. The Guardian. Available online at: https://www. theguardian.com/commentisfree/2018/feb/01/climate-change-action-trump (accessed May 30, 2019).

Merrill, K. (2012). The risks of dead reckoning: a postscriot on oil, climate change, and political time. J. Am. History 99, 252-255. doi: 10.1093/jahist/ jas101

Mitra, R. (2013). From transformational leadership to leadership transformations: a critical dialogic perspective. Commun. Theor. 23, 395-416. doi: $10.1111 /$ comt.12022
Nisbet, M. (2013). Nature's prophet: Bill McKibben as journalist, public intellectual and activist. Joan Shorenstein Center on the press, politics, and public policy: Discussion paper Series \#D-78, March 2013.

Nisbet, M. (2014). Disruptive ideas: public intellectuals and their arguments for action on climate change. WIREs Clim Change 5, 809-823. doi: 10.1002/ wcc. 317

Nisbet, M. (2018). The IPCC Report is a Wake-Up Call for Scholars, Advocates, and Philanthropists. Available online at: Medium.com. https://medium.com/ wealth-of-ideas/the-ipcc-report-is-a-wake- up-call-for-scholars-advocatesand-philanthropists-36415d4882f (accessed October 11, 2018).

Nisbet, M. (2019). The battle for public opinion on climate is over. Scientific American. Available online at: https://blogs.scientificamerican.com/ observations/the-battle-over-public-opinion-on-climate-is-over/?redirect=1 (accessed May 30, 2019).

Olson, K., and Goodnight, T. G. (1994). Entanglements of consumption, cruelty, privacy, and fashion: the social controversy over fur. Q. J. Speech 80, 249-276.

Peeples, J. (2011). Downwind: articulation and appropriation of social movement discourse. South. Commun. J. 76, 248-263. doi: 10.1080/1041794x.2010. 500516

Pezzullo, P. (2001). Performing critical interruptions: stories, rhetorical invention, and the environmental justice movement. Western J. Commun. 65, 1-25. doi: $10.1080 / 10570310109374689$

Pezzullo, P. (2011) Contextualizing boycotts and buycotts: the impure politics of consumer-based advocacy in an age of global ecological crises. Commun. Critic. Cult. Stud. 8, 124-145. doi: 10.1080/14791420.2011. 566276

Pezzullo, P. C. (2003). Resistiong 'National Breast Cancer Awareness Month': the rhetoric of counterpublics and their cultural performances. Q. J. Speech 89, 345-365. doi: 10.1080/00335630320001 60981

Poulakos, J. (1983). Toward a Sophistic definition of rhetoric. Philos. Rhetoric $16,35-48$.

Purcell, M. (2009). Resisting neoliberalization: communicative planning or counter-hegemonic movements?” Plann. Theor. 8, 140-165.

Reckson, L. (2014). "Gesture," in Keywords for American Cultural Studies, 2nd Edn (New York, NY: NYU Press). Available online at: http://keywords.nyupress.org/ american-cultural-studies/essay/gesture (accessed May 23, 2016).

Roberts, D. (2017, August 8). No, city pledges to get $100 \%$ renewable energy are not misleading. Vox. Available online at: https://www.vox.com/energyand-environment/2017/8/8/16111630/city-pledges-100-renewable-energy (accessed May 30, 2019).

Roberts, D. (2019, March 28). The green new deal and the case against incremental climate policy. Vox. Available online at: https://www.vox.com/energy-andenvironment/2019/3/28/18283514/green-new-deal-climate-policy (accessed April 8, 2019).

Schifeling, T., and Hoffman, A. (2017). Bill McKibben's influence on U.S. climate change discourse: shifting field-level debates through radical flank effects. Org. Environ. 1-21. doi: 10.1177/1086026617744278

Schneider, J., Schwarze, S., Bsumek, P., and Peeples, J. (2016). Under Pressure: Coal Industry Rhetoric and Neoliberalism. London: Palgrave MacMillan.

Simons, H.W. (1970). Requirements, prolems, and strategies: a theory of persuasion for social movements. Q. J. Speech 56, 1-11. doi: $10.1080 / 00335637009382977$

Skocpol, T. (2013). "Naming the problem: what it will take to counter extremism and engage Americans in the fight against global warming," in Symposium on the Politics of America's Fight Against Global Warming (Network, NY: Columbia School of Journalism and the Scholars Strategy). Available online at: https://scholars.org/sites/scholars/files/skocpol_captrade_ report_january_2013_0.pdf (accessed August 14, 2018).

Sprain, L., Peterson, N., Vickery, M., and Schutten, J. (2009). "Environmentalism 2.0: new forms of social activism," in Social Movement to Address Climate Change: Local Steps for Global Action, eds D. Endres, L. Sprain, and T. R. Peterson (Amherst, MA; New York, NY: Cambria Press), 337-360.

Step It Up (2007). Available online at: http://www.stepitup2007.org (accessed March 14, 2017).

Stewart, C., Smith, C., and Denton, R. (2007). Persuasion and Social Movements, 5th Edn. Prospect Heights, IL: Waveland press. 
Stormer, N. (2004). Articulation: a working paper on rhetoric and taxis. Q. J. Speech 90, 257-84. doi: 10.1080/0033563042000255516

Taylor, J. (2019, March 31). An open letter to Green New Dealers. Niskanen Center. Available online at: https://niskanencenter.org/blog/an-open-letter-to-greennew-dealers/ (accessed April 8, 2019).

Van Horn, J. (2018, January 2). Cities are moving toward clean, renewable energy. Sun Sentinel. Available online at: https://www.sun-sentinel.com/opinion/flop-cities-move-toward-clean-energy-20180101-story.html (accessed May 30, 2019).

Waldman, S., and Matthews, M. (2019, May 28). GOP criticizes its own on climate. $E$ \& $E$ News. Available online at: https://www.eenews.net/stories/1060410993 (accessed May 30, 2019).

White, R. (2011). Bill McKibben's emersonian vision. Raritan 31, 110-125. Available online at: https://search.proquest.com/docview/915261431?account. $\mathrm{d}=11667$

Yale Program on Climate Change Communication (2018). Six-Americas-2018Mar. Available online at: http://www.climatecommunication.yale.edu/about/ projects/global-warmings-six-americas/six-americas-2018-mar/ (accessed August 14, 2018).
Yearley, S. (2006). How many "Ends" of nature: making sociological and phenomenological sense of the End of Nature. Nat. Cult. 1, 10-21. doi: $10.3167 / 155860706780272006$

Ytterstad, A. (2015). Framing global warming: is that really the question? A realist, Gramscian critique of the framing paradigm in media and communication research. Environ. Commun. 9, 1-19. doi: 10.1080/17524032.2014. 919332

Conflict of Interest Statement: The authors declare that the research was conducted in the absence of any commercial or financial relationships that could be construed as a potential conflict of interest.

Copyright (c) 2019 Bsumek, Schwarze, Peeples and Schneider. This is an open-access article distributed under the terms of the Creative Commons Attribution License (CC $B Y)$. The use, distribution or reproduction in other forums is permitted, provided the original author(s) and the copyright owner(s) are credited and that the original publication in this journal is cited, in accordance with accepted academic practice. No use, distribution or reproduction is permitted which does not comply with these terms. 